\title{
Hepatoblastoma di Rumah Sakit Dr. Ciptomangunkusumo Jakarta: peran kemoterapi preoperatif
}

\author{
Ringoringo $H P^{*}$, Endang Windiastuti**, Djajadiman Gatot ${ }^{* *}$
}

Latar belakang: hepatoblastoma adalah tumor yang jarang ditemukan, namun merupakan tumor ganas primer hati yang paling banyak pada masa kanak-kanak. Sejak diperkenalkan rejimen kemoterapi untuk penanganan hepatoblastoma, angka kelangsungan hidup pasien meningkat.

Tujuan penelitian: untuk mengetahui profil hepatoblastoma anak di Departemen Ilmu Kesehatan Anak RS Cipto Mangunkusumo Jakarta dan menilai efektifitas kemoterapi preoperatif

Bahan dan Cara: sampel penelitian adalah semua pasien hepatoblastoma baru yang dirawat di Divisi Hematologi Onkologi Departemen IKA FKUI RSCM, Pebruari 1999 sampai dengan Pebruari 2005. Diagnosis ditegakkan berdasarkan gambaran histopatologi jaringan tumor. Sebelum mendapatkan kemoterapi, dilakukan pemeriksaan kadar alfa feto protein serum (AFP) dan pemeriksaan radiologis untuk menentukan stadium penyakit. Semua pasien mendapat kemoterapi menurut protokol PLADO yang terdiri dari sisplatin $(80 \mathrm{mg} / \mathrm{kgBB} / \mathrm{hari})$ dan doksorubisin $(30 \mathrm{mg} / \mathrm{kgBB} / \mathrm{hari})$. Evaluasi respons pengobatan dilakukan setelah pasien mendapat kemoterapi minimal sebanyak 2 siklus, berupa pemantauan klinis, pemeriksaan kadar AFP, dan pemeriksaan USG / CT scan abdomen. Operasi pengangkatan tumor dilakukan bila setelah pemberian kemoterapi massa tumor dianggap dapat direseksi.

Hasil: selama kurun waktu 6 tahun terdapat 14 pasien hepatoblastoma rentang usia antara 3 bulan sampai 54 bulan, dengan median 7 bulan. Enam pasien laki-laki dan 8 pasien perempuan. Semua pasien datang dengan keluhan utama perut yang semakin membesar. Kadar AFP meningkat pada semua pasien dengan median $323 \mathrm{ng} / \mathrm{ml}$. Pemeriksaan USG, CT scan dan MRI abdomen menunjukkan massa tumor ditemukan pada kedua lobus hati pada 7 pasien, sedang pada 7 pasien lainnya massa tumor hanya pada 1 lobus. Semua pasien datang pada stadium III. Biopsi hati yang dilakukan, menunjukkan gambaran histopatologi jenis epitelial fetal (9), epitelial mesenkimal (2), epitelial fetal-embrional (1), dan 1 jenis mesenkimal. Pada 1 pasien konfirmasi diagnosis hanya berdasarkan pemeriksan $C T$ scan abdomen dan kadar AFP. Pemberian kemoterapi preoperatif (protokol PLADO) pada 8 pasien menunjukkan respons yang cukup baik, yang ditandai oleh pengecilan massa tumor dan penurunan kadar AFP.

Kesimpulan: Umumnya pasien hepatoblastoma datang dalam stadium lanjut dan pemberian kemoterapi preoperatif menunjukkan respons yang baik untuk selanjutnya dapat dilakukan tindakan pembedahan.

Kata kunci : hepatoblastoma, kemoterapi, alfa-feto protein, sisplatin, doksorubisin 
$\mathcal{H}$ patoblastoma adalah tumor yang jarang ditemukan, namun merupakan tumor ganas primer hati yang paling banyak pada masa kanak-kanak. Data National Cancer Institute di AS menunjukkan $79 \%$ dari seluruh kanker hati adalah hepatoblastoma. Insidens hepatoblastoma meningkat dari 0,8:1000000 (tahun 1975-1979) menjadi 1,5:1000000 (tahun 1990-1995) anak di bawah usia 15 tahun. Insidens pada usia bayi berkisar 11,2: 1000000, dan semakin berkurang dengan meningkatnya usia. Pediatric Oncology Group melaporkan dari 106 kasus hepatoblastoma ternyata usia rata-rata saat pertama kali didiagnosis adalah 19 bulan, hanya 4\% kasus terjadi di atas usia 4 tahun. ${ }^{1-4}$ Tomlinson melaporkan dari 1256 kasus tumor ganas dan tumor jinak primer hati ternyata $43 \%$ kasus adalah hepatoblastoma. Hepatoblastoma banyak dikaitkan dengan Beckwith-Weidemann syndrome (BWS), hemihipertrofi, familial adenomatous polyposis (FAP), dan bayi berat lahir rendah. ${ }^{1,25,6,7,8}$

Kusano dkk $^{9}$ melaporkan bahwa pemberian kemoterapi preoperatif kombinasi sisplatin dan doksorubisin sebanyak 4 siklus pada 7 pasien hepatoblastoma dapat mengecilkan massa tumor dan penurunan kadar AFP dari rata-rata $1,38 \times 10^{4} \mathrm{ng} / \mathrm{ml}$ menjadi rata-rata $999 \mathrm{ng} / \mathrm{ml}$. Hepatektomi yang kemudian dilakukan memberikan prognosis yang lebih baik dengan masa remisi (tanpa rekurens) selama 47150 bulan.

Makalah ini melaporkan profil pasien hepatoblastoma di Departemen Ilmu Kesehatan Anak RS. Dr. Cipto Mangunkusumo, Jakarta dan menilai efektifitas kemoterapi preoperatif.

\section{Metoda}

Penelitian ini dimulai sejak bulan Pebruari 1999 sampai dengan Pebruari 2005, terhadap semua pasien hepatoblastoma baru berusia $<16$ tahun yang dirawat

\footnotetext{
Alamat korespondensi:

${ }^{*}$ Dr. Ringoringo HP, SpA. Kepala UPF Anak RSUD Banjarbaru Kalimantan Selatan

** Departemen Ilmu Kesehatan Anak FKUI-RSCM.

Jl. Salemba no. 6, Jakarta 10430. Telepon: 021-3907744, 31901170 Fax.021-3913982.
}

di Divisi Hematologi Onkologi Departemen IKA FKUI RSCM dan belum pernah mendapat kemoterapi sebelumnya. Diagnosis hepatoblastoma ditegakkan berdasarkan gambaran histopatologi jaringan tumor. Sebelum pemberian kemoterapi, selain pemeriksaan darah tepi lengkap, uji fungsi hati, uji fungsi ginjal dan ekokardiografi, dilakukan juga pemeriksaan alfa feto protein serum (AFP) dan pemeriksaan pencitraan (USG/CT-scan/MRI) untuk menentukan penyebaran tumor dan stadium penyakit. Semua pasien mendapat kemoterapi menurut protokol PLADO yang terdiri dari sisplatin $\left(80 \mathrm{mg} / \mathrm{m}^{2} /\right.$ hari) dan doksorubisin $\left(30 \mathrm{mg} / \mathrm{m}^{2} / \mathrm{hari}\right)$. Satu siklus kemoterapi menurut protokol PLADO terdiri dari pemberian sisplatin $\left(80 \mathrm{mg} / \mathrm{m}^{2} /\right.$ hari $)$ pada hari pertama, dilanjutkan dengan doksorubisin (30 $\mathrm{mg} / \mathrm{m}^{2} /$ hari) pada hari kedua dan hari ketiga. Siklus kemoterapi ini diulang setiap 3 minggu, sampai sebanyak 4-6 siklus. Evaluasi respons tumor terhadap kemoterapi dilakukan setelah pasien mendapatkan kemoterapi minimal 2 siklus, yaitu dengan pemantauan klinis, pemeriksaan kadar AFP dan pemeriksaan USG/CT scan/MRI abdomen. Dinyatakan respons sempurna apabila masa tumor menghilang disertai kadar AFP yang normal dan respons parsial bila didapatkan pengecilan masa tumor disertai penurunan kadar AFP. Pada keadaan masih unresectable maka pemberian kemoterapi ditambah 2-4 siklus lagi sampai dinilai tumor dapat direseksi.

\section{Hasil penelitian}

Dalam kurun waktu 6 tahun terdapat 14 pasien hepatoblastoma yang terdiri dari 6 anak laki-laki dan 8 anak perempuan dengan rentang usia 3 bulan sampai 54 bulan (median umur 7 bulan), dan 7 pasien berusia antara 3-8 bulan. Keadaan gizi semua pasien baik. Semua pasien datang dengan keluhan utama perut yang semakin membesar, sedangkan yang disertai venektasi 7 pasien. Semua pasien menunjukkan hepatomegali, 13 di antaranya dengan ukuran lebih dari $5 \mathrm{~cm}$. Pada 3 pasien ditemukan splenomegali.

Pemeriksaan darah tepi menunjukkan anemia pada 12 pasien; jumlah leukosit dan trombosit normal pada semua pasien. Semua pasien menunjukkan kadar ureum dan kreatinin darah yang normal. Semua pasien menunjukan kadar bilirubin direk dan bilirubin indirek yang normal. 
Berdasarkan pemeriksaan USG, CT scan dan MRI abdomen ditemukan massa tumor di kedua lobus hati pada 7 pasien, 6 pasien di lobus kanan dan 1 pasien di lobus kiri. Semua pasien menunjukkan penyebaran / staging penyakit pada stadium III. Karena itu semua pasien mendapatkan kemoterapi preoperatif. Biopsi hati dilakukan dengan cara fine needle aspiration biopsy (FNAB) pada 9 pasien dan open biopsy pada 4 pasien. Pada 1 pasien diagnosis hanya ditegakkan berdasarkan pemeriksaan $C T$ scan abdomen dan peningkatan kadar AFP serum, tanpa biopsi. Karakteristik pasien dan tumor tertera pada Tabel 1. hidup, 2 pasien pasien meninggal (1 kasus meninggal karena komplikasi bronkopneumonia, dan 1 kasus meninggal pasca operasi hernia inguinalis inkarserata), dan 4 pasien tidak kontrol lagi. (Gambar 1)

\section{Diskusi}

Di dalam kepustakaan dikemukakan bahwa hampir semua kasus hepatoblastoma terjadi pada usia yang masih sangat muda, $90 \%$ kasus terjadi pada usia $£ 5$

Tabel-1 Karakteristik pasien dan jenis tumor

\begin{tabular}{lllllllllll}
\hline Pasien & $\begin{array}{l}\text { Usia } \\
\text { (bulan) }\end{array}$ & $\begin{array}{l}\text { Jns } \\
\text { kel }\end{array}$ & $\begin{array}{l}\text { Hb } \\
(\mathrm{g} / \mathrm{dl})\end{array}$ & $\begin{array}{l}\text { LED } \\
(\mathrm{mm})\end{array}$ & $\begin{array}{l}\text { AFP } \\
(\mathrm{ng} / \mathrm{ml})\end{array}$ & $\begin{array}{l}\text { SGOT } \\
(\mathrm{IU})\end{array}$ & $\begin{array}{l}\text { SGPT } \\
(\mathrm{IU})\end{array}$ & $\begin{array}{l}\text { Lokasi } \\
\text { tumor }\end{array}$ & $\begin{array}{l}\text { KT } \\
\text { siklus }\end{array}$ \\
\hline 1 & 3 & $\mathrm{~L}$ & 11,1 & & 350 & 10 & 5 & ka-ki & e-fe & 6 \\
2 & 13 & $\mathrm{P}$ & 10,2 & 40 & 306 & 60 & 20 & ka & e-f & 2 \\
3 & 18 & $\mathrm{P}$ & 9,5 & 65 & 20000 & 281 & 61 & ka & e-f & 4 \\
4 & 24 & $\mathrm{P}$ & 7,5 & 80 & 154 & 10 & 8 & ka & $\mathrm{m}$ & 2 \\
5 & 54 & $\mathrm{P}$ & 10,1 & 25 & 10000 & 31 & 24 & ka-ki & e-f & - \\
6 & 42 & $\mathrm{P}$ & 10,0 & 54 & 5,9 & 12 & 10 & ka-ki & e-f & - \\
7 & 4,5 & $\mathrm{P}$ & 8,5 & & 156,6 & 59 & 29 & ka & e-m & - \\
8 & 3 & $\mathrm{~L}$ & 10,3 & & 340 & 29 & 10 & ka-ki & e-f & - \\
9 & 7 & $\mathrm{~L}$ & 7,7 & & 108,1 & 25 & 12 & ki & e-m & - \\
10 & 18 & $\mathrm{~L}$ & 8,9 & & 21282 & 88 & 25 & ka & e-f & 9 \\
11 & 14 & $\mathrm{~L}$ & 11,2 & 80 & 100000 & 40 & 56 & ka-ki & e-f & 5 \\
12 & 4,5 & $\mathrm{~L}$ & 10,9 & & 173 & 38 & 44 & ka & e-f & 10 \\
13 & 8 & $\mathrm{P}$ & 8,4 & 140 & 100000 & 50 & 8 & ka-ki & e-f & 2 \\
14 & 2,8 & $\mathrm{P}$ & 8,8 & & 175 & 32 & 22 & ka-ki & & - \\
\hline
\end{tabular}

Keterangan $: \mathrm{Hb}=$ hemoglobin, $\mathrm{LED}=$ laju endap darah,Jns kel= jenis kelamin

$\mathrm{PA}=$ hasil pemeriksaan patologi anatomi

$\mathrm{ka}=$ kanan, $\mathrm{ki}=$ kiri, ka-ki = kanan dan kiri, $\mathrm{KT}=$ kemoterapi

$\mathrm{e}-\mathrm{fe}=$ epitelial fetal dan embrional, $\mathrm{e}-\mathrm{f}=$ epitelial fetal,

$\mathrm{m}=$ mesenkimal, e-m = epitelial mesenkimal

Diantara 14 pasien hepatoblastoma hanya 8 pasien yang mendapat kemoterapi preoperatif. Evaluasi respons tumor terhadap kemoterapi dilakukan setelah mendapat minimal 2 siklus, didapatkan semua pasien memperlihatkan respons parsial, yaitu pengurangan massa tumor (dibuktikan dengan palpasi, pemeriksaan USG abdomen dan atau $C T$ scan abdomen) dan penurunan kadar AFP, sebagai contoh tampak pada Gambar-1. Dua pasien yang masih hidup dan kontrol teratur (operablel resectable) tidak dapat dioperasi karena keterbatasan sarana operasi dan fasilitas penunjang setelah operasi. Sampai akhir penelitian ini 2 pasien masih tahun, 68\% kasus terjadi pada usia $£ 2$ tahun, dan $4 \%$ kasus terdeteksi sejak lahir. Pada penelitian ini rerata usia adalah 15 bulan. Umumnya hepatoblastoma lebih sering ditemukan pada anak laki-laki dengan rasio anak laki-laki: perempuan berkisar dari 1,2-3,3., ${ }^{1,2,10-13}$ Sebaliknya pada penelitian ini lebih sering ditemukan pada anak perempuan, mungkin karena sampel terlalu sedikit.

Keadaan umum dan status gizi pasien baik. Hal ini sesuai dengan kepustakaan yang menyatakan bahwa keadaan klinis pasien cukup baik kecuali bila penyakit sudah berat sekali. ${ }^{1,2,5}$ Pada 6 pasien tumor terdapat di lobus kanan; di lobus kiri hanya pada 1 pasien dan di 


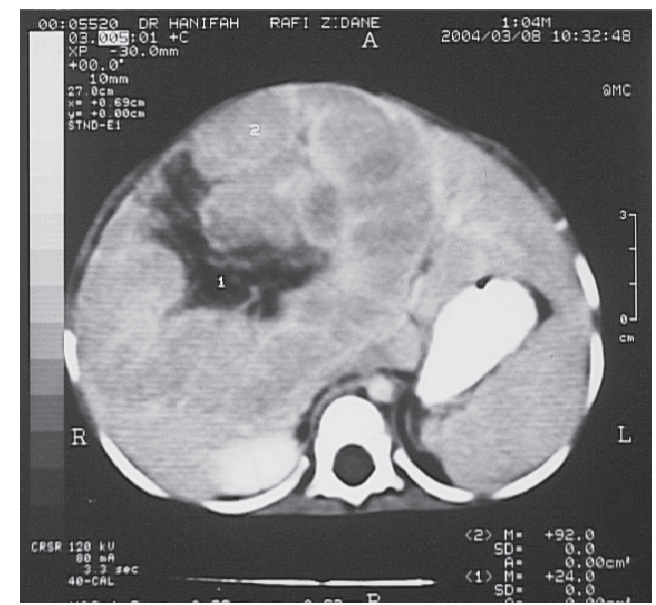

sebelum kemoterapi

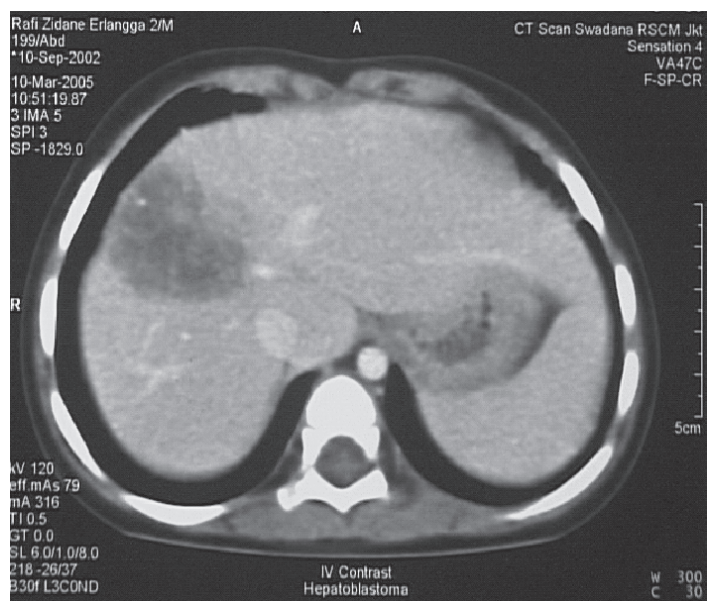

setelah kemoterapi

Gambar 1. Gambar CT scan abdomen sebelum dan sesudah kemoterapi.

kedua lobus pada 7 pasien. Hal ini berbeda dengan kepustakaan yang menyatakan letak tumor di lobus kanan 3 kali lebih sering dari pada di lobus kiri, dan hanya 20\%-30\% tumor terletak di kedua lobus. ${ }^{12,13}$ Diameter tumor berkisar $5-22 \mathrm{~cm}$, dengan berat tumor berkisar dari 150-1400 gram. ${ }^{1,13,14}$

Pada pemeriksaan darah tepi hampir semua pasien menunjukkan anemia, sedangkan jumlah trombosit dalam batas normal. Berbeda dengan beberapa kepustakaan yang menyebut anemia terdapat pada $70 \%$ kasus, dan trombositosis terdapat pada 50\% kasus. Ternyata pada pasien hepatoblastoma terdapat peningkatan kadar trombopoitin di jaringan tumor yang berperan pada pembentukan trombosit. ${ }^{15}$ Pemeriksaan LED meningkat pada semua pasien yang diperiksa dengan rata-rata $69 \mathrm{~mm} / \mathrm{jam}$ pada penelitian ini, karena itu pemeriksaan LED perlu dipertimbangkan pada pasien hepatoblastoma. Hanya sedikit pasien pada penelitian ini yang menunjukkan kelainan enzimenzim hati; hal ini sesuai dengan kepustakaan bahwa pada kasus hepatoblastoma, enzim-enzim hati jarang terganggu, SGOT/SGPT sedikit meningkat pada 15\%-30\% kasus, bilirubin sedikit meningkat pada 20\%-25\% kasus, dan alkali fosfatase sedikit meningkat pada $60 \%$ kasus. ${ }^{1,2,4,5,10,13}$ Pemeriksaan AFP harus dilakukan pada semua kasus hepatoblastoma karena 80\%-98\% kasus menunjukkan peningkatan kadar AFP. ${ }^{1,2,4,5,10,13,16}$ Hampir semua pasien hepatoblastoma mempunyai kadar AFP > $100 \mathrm{ng} / \mathrm{ml} .{ }^{4}$ Dalam penelitian ini kadar AFP meningkat pada hampir semua pasien dengan median $323 \mathrm{ng} / \mathrm{ml}$.
Pada penelitian ini dari 13 pasien yang dilakukan biopsi, 9 pasien menunjukkan gambaran histopatologi jenis epitelial fetal, 2 pasien jenis epitelial mesenkimal, 1 pasien jenis epitelial fetal-embrional, dan 1 pasien jenis mesenkimal. Gambar-2 memperlihatkan gambaran jenis epitelial fetal dan embrional. Beberapa penulis melaporkan bahwa jenis epitelial terdapat pada 56\% kasus yang terdiri dari epitelial fetal pada 31\% kasus, epitelial fetal-embrional pada 19\% kasus, epitelial makrotrabekular pada 3\% kasus, epitelial anaplastik pada 3\% kasus; serta jenis campuran epitelial dan mesenkimal pada $44 \%$ kasus. Jenis eipitelial fetal mempunyai prognosis yang lebih baik, sedangkan jenis epitelial embrional dan epitelial anaplastik mempunyai prognosis buruk. ${ }^{2,5,13}$ (Gambar 2)

Cara penentuan staging hepatoblastoma bermacam-macam, namun yang paling sering digunakan adalah menurut Intergroup Hepatoma Studies dan International Society of Pediatric Oncology (SIOP), tertera pada Tabel 2:1,2,3,4,12

Berdasarkan staging tersebut, semua pasien dalam penelitian ini tergolong dalam stadium III, yaitu masa tumor di hati unresectable dan tidak ada metastasis. Hal ini mungkin terjadi karena keterlambatan berobat.

Tata laksana hepatoblastoma yang paling utama adalah pembedahan yang diikuti dengan kemoterapi. Beberapa kepustakaan menyatakan bahwa 40\%-60\% kasus hepatoblastoma tidak dapat direseksi (unresectable) pada saat diagnosis, akan tetapi pemberian kemoterapi preoperatif dapat mengecilkan masa tumor sehingga 85\% kasus dapat direseksi. ${ }^{1-3,13}$ Akhir-akhir ini 


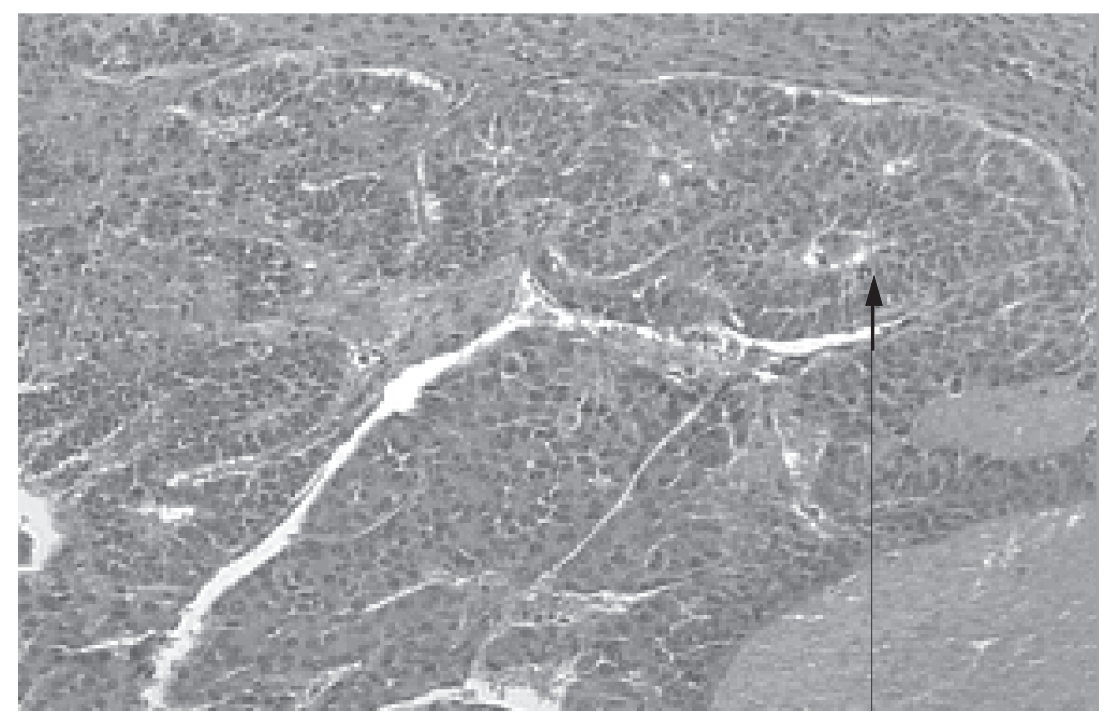

Gambar 2. Hepatoblastoma dengan gambaran histopatologi jaringan jenis epitelial fetal dan embrional. Komponen fetal terbentuk dari sel-sel tumor dengan sitoplasma yang banyak mengandung eosinofil, sedangkan komponen embrional terbentuk dari sel-sel tumor dengan inti yang besar dan sitoplasma yang sempit membentuk tubulus dan pita.

Tabel-2. Penentuan staging hepatoblastoma

\begin{tabular}{lll}
\hline \multicolumn{1}{c}{ Stage } & US Intergroup Hepatoma Studies & SIOP \\
\hline I & dapat direseksi total & 3 sektor berdekatan bebas tumor \\
II & sisa tumor (+) secara mikroskopik & 2 sektor berdekatan bebas tumor \\
III & sisa tumor (+) secara makroskopik, & 2 sektor yang tidak \\
& tidak dapat direseksi, atau & berdekatan atau 1 sektor \\
& kapsul tumor ruptur & berdekatan bebas tumor \\
IV & metastasis & tidak ada sektor yang bebas tumor \\
\hline
\end{tabular}

kemoterapi preoperatif tetap diberikan meskipun tumornya dapat direseksi total. Ehrlich melaporkan 91\% dari 22 kasus hepatoblastoma yang diberikan 3-6 siklus kemoterapi preoperatif memberikan respons yang baik; sehingga 19 dari 20 pasien dapat direseksi total. ${ }^{17}$ Penelitian lain menyatakan bahwa kombinasi kemoterapi preoperatif dan pembedahan memberikan angka survival $82 \%$ dengan median follow-up 8 tahun. ${ }^{14}$ Pada penelitian ini 8 kasus (6 kasus gambaran histopatologinya adalah jenis epithelial fetal, 1 kasus jenis fetal embrional, 1 kasus jenis mesenkimal) mendapat kemoterapi preoperatif dan menunjukkan respons perbaikan yang ditandai dengan pengecilan masa tumor dan penurunan kadar AFP. Sayangnya 4 kasus tidak kontrol lagi setelah kondisi klinisnya membaik, 1 kasus meninggal karena komplikasi bronkopneumonia, dan
1 kasus meninggal pasca operasi hernia inguinalis inkarserata. Dua kasus yang masih hidup dan kontrol teratur, adalah pasien yang tumornya dapat direseksi total. Namun karena keterbatasan sarana operasi dan fasilitas penunjang pasca operasi serta biaya yang tidak sedikit maka pada kedua kasus tersebut tindakan pembedahan belum dapat dilakukan.

Transplantasi hati dilakukan bila masa tumor mengenai kedua lobus, bila sudah ada penyebaran ekstrahepatik atau bila terjadi rekurensi setelah pembedahan. ${ }^{1-5}$ Reyes dkk. melaporkan 31 pasien tumor hati yang unresectable yang mendapat kemoterapi preoperatif dan kemudian menjalani hepatektomi total dan transplantasi hati, angka harapan hidup 5 tahun pasca operasi adalah $83 \%$ untuk hepatoblastoma dan $68 \%$ untuk hepatocellular carcinoma. ${ }^{18}$ 
Sari Pediatri, Vol. 7, No. 4, Maret 2006

Metastasis hepatoblastoma paling sering adalah ke paru. Pada 20\% kasus, metastasis sudah ditemukan pada awal diagnosis hepatoblastoma. Lokasi metastasis hepatoblastoma lainnya adalah tulang, otak, mata, ovarium, pembuluh darah hepatika, vena porta, dan vena kava inferior.. ${ }^{1,2,4,5,13}$ Pada penelitian ini tidak ditemukan metastasis.

Prognosis pasien sangat tergantung pada stadium penyakit saat awal diagnosis, gambaran histopatologi jaringan hati, kadar AFP, pemberian kemoterapi preoperatif, tumor soliter atau multipel, tingkat mitosis masa tumor, dan dilakukan atau tidak dilakukan tindakan pembedahan. Prognosis terbaik bila stadium penyakit adalah stadium I, gambaran histopatologi jenis epitelial fetal, kadar AFP antara 100-1000000 ng/ml, diberikan kemoterapi preoperatif, tumor soliter, tingkat mitosis rendah, dan segera dilakukan tindakan pembedahan. ${ }^{1,2,3,13,14,16,17}$ Feusner dkk. ${ }^{19}$ melaporkan rekurens hepatoblastoma pada 10 dari 33 pasien stadium I, 6 pasien di antaranya dengan metastasis di paru. Pada penelitian ini meskipun pasien yang mendapat kemoterapi preoperatif terdiagnosis saat stadium III, namun pada sebagian besar (6 dari 8) pasien gambaran histopatologi jaringannya adalah jenis epitelial fetal sehingga prognosisnya akan lebih baik seandainya tindakan operasi segera dilakukan.

\section{Kesimpulan}

Pada penelitian ini usia rerata pasien hepatoblastoma adalah 15 bulan, dan lebih sering pada anak perempuan. Semua pasien datang dengan keluhan utama perut yang semakin membesar. Kadar AFP meningkat pada semua pasien dengan median $323 \mathrm{ng} /$ ml. Laju endap darah meningkat pada semua pasien yang diperiksa dengan rata-rata $69 \mathrm{~mm} / \mathrm{jam}$. Pemeriksaan radiologi menunjukkan masa tumor, di kedua lobus hati pada 7 pasien dan 7 lainnya pada 1 lobus hati. Dari 13 pasien yang dilakukan biopsi, 9 pasien menunjukkan gambaran histopatologi jenis epithelial fetal, 2 pasien jenis epithelial mesenkimal, 1 pasien jenis epithelial fetal-embrional, dan 1 pasien jenis mesenkimal. Semua pasien datang dalam stadium III. Pada 8 pasien yang mendapat kemoterapi menurut protokol PLADO, semuanya memperlihatkan perbaikan yang ditandai dengan pengecilan massa tumor dan penurunan kadar AFP.

\section{Daftar Pustaka}

1. Tomlinson GE, Finegold MJ. Tumors of the liver. Dalam: Pizzo PA, Poplack DG, penyunting. Edisi ke-empat. Principles and practice of pediatric oncology. Philadelphia: Lippincott Williams \& Wilkins; 2002. h. 847-64.

2. Stocker JT. Hepatic tumors in children. Dalam: Suchy FJ, Sokol RJ, Balisteri WF, penyunting. Edisi kedua. Liver disease in children. Philadelphia: Lippincott Williams \&Wilkins; 2001. h. 915-47.

3. Herzog CE, Andrassy RJ, Eftekhari F. Chilhood cancers: Hepatoblastoma. Oncologist 2000;5:445-453.

4. Ikeda H, Tsuchida Y. Hepatic tumours. Dalam: Voute PA, Kalifa C, Barret A, penyunting. Edisi ke-empat. Cancer in children: clinical management. New York: Oxford University Press;1999. h. 308-23.

5. McCarville ME, Furman WL. Hepatoblastoma. E-Medicine. March 2005.

6. Tanimura M, Matsui I, Abe J, Ikeda H, Kobayashi N, Ohira M, dkk. Increased risk of hepatoblastoma among immature children with a lower birth weight. Cancer Research 1998; 58:3032-5.

7. Ribons LA, Slovis L. Hepatoblastoma and birth weight. J Pediatr 1998; 132:750-6.

8. Czauderna P, Perilongo G. Hepatoblastoma. Orphanet Encyclopedia. July 2004. http:/www.orphanet/data/patho/ GB/uk-Hepatoblastoma.pdf.

9. Kusano T, Aoki H, Kinjo T, Miyazato H, Shimoji H, Isa T, $\mathrm{dkk}$. Successful resection for advanced hepatoblastoma, combined with perioperative chemotherapy. J Hepatobiliary Pancreat Surg. 2000; 7:410-6.

10. Leventhal BG. Neoplasms of the liver. Dalam: Behrman RE, Kliegman RM, Nelson WE, Vaughan VC, penyunting. Edisi ke-empatbelas. Nelson textbook of pediatrics. Philadelphia : WB Saunders Company; 1992. h. 1316-7.

11. Ortega JA, Douglass EC, Feusner JH, Reynolds M, Quinn JJ, Finegold MJ, dkk. Randomized comparison of cisplatin/vincristin/fluorouracil and cisplatin/ continuos infusion doxorubicin for treatment of pediatric hepatoblastoma: a report from the Children's Cancer Group and the Pediatric Oncologic Group. J Clin Oncol 2000; 18:2665-75.

12. Pritchard J, Brown J, Shafford E, Perilongo G, Brock P, Mireaux CD, dkk. Cisplatin, doxorubicin, and delayed surgery for childhood hepatoblastoma: a successful approach- results of the first prospective study of the International Society of Pediatric Oncology. J Clin Oncol 2000; 18:3819-28. 
13. Doctor'Doctor. Hepatoblastoma. 2004. Didapat dari http:/ /www.thedoctorsdoctor.com/diseases/liver-hepatoblastoma.htm

14. Carseller A, Blandchard H, Champagne J, St-Vil D, Bensoussan AL. Surgical resection and chemotherapy improve survival rate for patients with hepatoblastoma. J Pediatr Surg 2001; 36(5):755-9.

15. Komura E, Matsumura K, Kato T, Tahara T, Tsunoda Y, Sawada T. Thrombopoietin in patients with hepatoblastoma. Stem Cells 1998; 16:329-333.

16. Tornout JM, Buckley JD, Quinn JJ, Feusner JH, Krailo MD, King DR, dkk. Timing and magnitude of decline in alpha-fetoprotein levels in treated children with unresectable or metastatic hepatoblastoma are predic- tors of outcome: a report from the Children's Cancer Group. J Clin Oncol 1997; 15:1190-7.

17. Ehrlich PF, Greenberg ML, Filler RM. Improved longterm survival with preoperative chemotherapy for hepatoblastoma. J Pediatr Surg 1997; 32:999-1002.

18. Reyes JD, Carr B, Dvorchik I, Kochosis S, Jaffe R, Gerber $\mathrm{D}$, dkk. Liver transplantation and chemotherapy for hepatoblastoma dan hepatocellular cancer in childhood and adolescence. J Pediatr 2000; 136:795-804.

19. Feusner JH. Treatment of pulmonary metastasis of initial stage I hepatoblastoma in childhood. Report from the Children's Cancer Group. Cancer 1993; 71:859-64. 